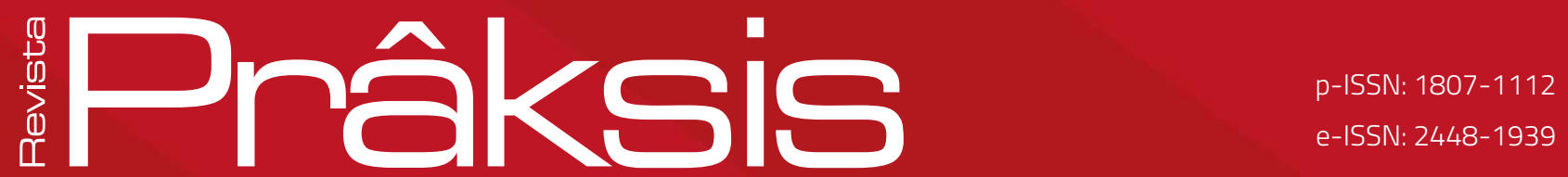

Recebido em: 02 de março de 2019

Aprovado em: 21 de julho de 2019

Sistema de Avaliação: Double Blind Review RPR |a. 16|n. 3|p. 67-79| set./dez. 2019

DOI: https://doi.org/10.25112/rpr.v3i0.1978

\title{
DESIGNING AND MANAGING SMART SERVICES IN THE SOCIAL AND HEALTH SECTOR
}

\section{PROJETANDO E GERENCIANDO SERVIÇOS} INTELIGENTES NO SETOR SOCIAL E DE SAÚDE

\section{Katja Valkama}

Principal lecturer, PhD Adm., MSSc. E-mail: katja.valkama@hamk.fi

\section{Merja Salminen}

Head of Degree Programme, Social services and Social and Health Care (Master), PhD.

E-mail: merja.salminen@hamk.fi 


\section{ABSTRACT}

In this article, smart services are considered in the social and health care context. It is argued that new tools and information will help professionals, managers, and decision makers solve problems. Artificial intelligence, personalized medicine, social innovations, and the responsible use of social and health care data will create new services and improve access to all services. Organizational intelligence, smart services, and smart care are just some examples of the rhetoric that strengthens today's discussions on social and health care in Finland. In conclusion, it is argued that developing and using smart services in social and health care have to be based on the user's active role in smart service design processes. Management structures should support and encourage practices where the user's involvement and participation is self-evident.

Keywords: Smart social and health care. Services. Wellbeing.

\section{RESUMO}

Neste artigo, os serviços inteligentes são analisados no contexto social e de saúde. Argumenta-se que as novas ferramentas e informações ajudarão os profissionais, os gerentes e os tomadores de decisão a resolverem problemas. A inteligência artificial, a medicina personalizada, as inovações sociais, bem como o uso responsável de dados sociais e de saúde criarão novos serviços e melhorarão o acesso a todos os serviços. A inteligência organizacional, os serviços inteligentes e o atendimento inteligente são apenas alguns exemplos da retórica que fortalece as discussões atuais sobre a assistência social e de saúde na Finlândia. Em conclusão, argumenta-se que o desenvolvimento e o uso de serviços inteligentes em serviços sociais e de saúde devem se basear no papel ativo do usuário nos processos de desenho de serviços inteligentes. As estruturas de gestão devem apoiar e encorajar práticas onde o envolvimento e a participação do usuário sejam evidentes.

Palavras-chave: Assistência social e saúde inteligente. Serviços. Bem-estar. 


\section{INTRODUCTION}

In the School of Wellbeing, our activities in education, development, and research focus on designing and managing smart services in the social and health care sector. The profile is also divided into three lower level categories: (1) developing digital social and health care services, (2) preparing for and managing crises and critical situations, and (3) promoting cultural wellbeing. However, this article will focus only on the main profile.

This article will answer three questions: (1) Why was this focal point chosen? (2) What do we mean by the term "smart"?, and (3) What are smart services in social and health care settings?

Why focus on terms? Terms are extremely important in social and health care. The terms and their use directly illuminate the values behind discussions. Rhetoric influences legislation, recommendations, guidelines, and actions (NIIRANEN, 2002; MÄLKIÄ, 1998). The Finnish word "älykäs" used in our definition is complex - it can be translated as "smart" and "intelligent". Therefore, the use of "smart" and "intelligent" has become diffuse. These terms are also used differently in different contexts, and therefore their connotation varies. It is crucial to try to define this term in the social and health care context to be able to clarify what we are trying to achieve and how. The terms "smart" and "intelligent" are used in this article as they have been used in the sources, although the authors themselves do not differentiate between them in the Finnish translation.

It is also relevant to define the term "wellbeing". There are many factors affecting wellbeing, and its definition can cover everything from the practicing nursing profession to unregulated services provided by a variety of trained and untrained providers of wellbeing services. The School of Wellbeing offers education on the bachelor's level in social work, teachers for early education, nurses, and public health nurses, and on the master's level in Social and Health Care Development and Management (general and specialized in crises) and the masters' level in Promoting Wellbeing through Culture and Art. Most of the professions taught at our school are regulated and controlled by Valvira, the National Supervisory Authority for Welfare and Health. So our definition of wellbeing is tightly connected to our basic taskeducation and the fields covered by it.

\section{THE REASON TO FOCUS ON THESE THEMES}

The ever-changing world around us also shapes our society. The same factors that influence our everyday life also influence the social and health care sector and its policies. The megatrends commonly listed as having an influence are the evolving population structure, globalization, the transformation of work, technological developments, and involved individuals. 
There are several ongoing and anticipated changes in the social and health care sector. There has long been intentions to reform the social and health care service provision, but so far attempts have failed due to constitutional problems. Social security refers to society's commitment to ensure everyone's wellbeing through comprehensive a social and health care system. The changes challenge the serviceprovision system. New tools and ways of working are required. The emphasis must be on prevention and promotion that will support an individual's quality of life, participation, equality, and social networks. These can be more cost-effective than previous tools and can reduce the need for corrective measures (MINISTRY OF SOCIAL AFFAIRS AND HEALTH, 2018).

It is argued that new tools and information will help professionals and decision makers solve problems. Artificial intelligence, personalized medicine, social innovations, and the responsible use of social and health care data will create new services and improve access to all services. Actions promoting wellbeing, health, and employment are a worthwhile investment in the future, which will help Finland remain a model country for sustainable growth in the health and social care sector (MINISTRY OF SOCIAL AFFAIRS AND HEALTH, 2018).

The Finnish welfare system has traditionally been based on ideas of universalism, altruism, and equality, as in other Nordic countries. The idea of a society securing all citizens grew slowly but has gained strong support among the citizens. Studies show that even in the middle of an economic recession, people are willing to maintain social and health services at the established level. Cutting social and health services is always the last thing people are willing to do, and the majority of the population supports the welfare state (e.g., MUURI; AALTO; MANDERBACKA; ARFFMAN, 2019; HAAVISTO; KILJUNEN, 2011; BLOMBERG-KROLL, 2011; SILTANIEMI; PERÄLAHTI; ERONEN; SÄRKELÄ; LONDÉN, 2009; BLOMBERGKROLL, 1999).

It is important to develop and renew the system according to the changing world. Although the citizens support the ideology and tradition behind social and health services, the rhetoric of New Public Management and neo-liberalism has entered the whole sweep of the Finnish social and health care sector. Terms like commercialization, purchaser-provider split, customer-centered, productization, and contracting have become everyday language even in social and health services. The predominant trend has been to learn from and quickly implement all new trends (see LEHTO, 2001). This reconstruction should always have a critical element in it. The new ideologies, trends, and models to operate should always be reflected against the values the social and health services are built on (e.g., VALKAMA, 2012; JULKUNEN, 2006).

Organizational intelligence, smart services, and smart care are just some examples of the rhetoric that play out in today's discussions on social and health care. Smart specialization is a relatively new term. 
The term spread quickly from academic research to mainstream innovation and regional policy in the EU. The concept was generated in 2009 by the research group "Knowledge for Growth" and especially by economist Dominic Foray (FORAY, 2009; FORAY et al., 2015; VIRKKALA, 2015). "Smart services" is often used as a synonym for digital or electronic services. What do we really mean by smart social and health care services? According to the legislation, the public sector is responsible for the provision of social and health care services in Finland. Services are mainly provided by public organizations, so we will next focus on organizational intelligence, or "smartness."

\section{ORGANIZATIONAL INTELLIGENCE}

Why is it important for an organization to be smart?

Yolles (2005) defines organizational intelligence as a concept that is focused on ideas of knowledge. However, this is not enough; intelligence must extend further. Yolles (2005, p. 102) continues: "Intelligence is closely linked with the ability of a singular or plural actor to discern attributes of cultural knowledge, and in particular to efficiently and effectively discriminate, relate, manipulate and apply that knowledge in a variety of phenomenal environments. For plural actors this facilitates collective viability."

There are many applications for the notion of organizational intelligence, and the idea of the intelligent organization is intimately linked with the idea of the learning organization. In many cases, organizational intelligence is linked to knowledge management, which is argued to be solvable by utilizing technology for this function. However, Yolles (2005) argues that it is intelligence rather than knowledge management that can effectively deal with the fitness of an organization. We have shown that the use of the viable systems approach can dig deep into the reasons why certain pathologies exist and how they can be managed.

According to studies, so-called intelligent/smart organizations succeed better than unintelligent organizations (MATHESON; MATHESON, 2001; VIRTANEN; STENVALL, 2014). The success is based on a more determined and clearer definition of objectives, more effective utilization of resources, and heightened sensitivity in recognizing changes in the environment and the skill to prepare for these changes (VIRTANEN; STENVALL, 2014).

One main implication for organizational intelligence is smart management. A smart organization drives from a deep understanding of management, leadership, strategic planning, personnel resources, process management, and defining outcomes (VIRTANEN; STENVALL, 2014).

According to Stenvall and Virtanen (2015), organizational intelligence entails different ways of acting, which relate to leadership, strategy, planning, resources, partnerships, and processes. According to James 
G. March (2010), organizational intelligence can be divided into two different categories. First, it can take place as effective adaptability to inner and outer surroundings; this is called adaptive intelligence. The second form of intelligence is interpretative intelligence, which interprets reality in a purposeful way.

An organization does not just comprise physical space; it also includes spiritual and virtual spaces. Therefore an organization has both an informal and formal network. Openness and partnership are very important in today's society. In this aspect, public organizations differ from non-public organizations, which have no accountability to society. They also have no interest in partnering with society. Their objective can only be to make a profit (STENVALL; VIRTANEN, 2015).

\section{SMART PUBLIC ORGANIZATION}

A smart public organization acknowledges the different ways to utilize knowledge. Especially important is the ability to foresee future trends and developments. Although foresight is not enough, there must also be the ability to use these predictions. A smart organization is able to foster cooperation, developing the interaction between multiple actors within and outside the organization. A smart public organization is able to identify the needs and wants of the users of its services. Therefore, it is essential to renew and develop services that are customer-oriented (VIRTANEN; STENVALL, 2014).

Smart comprehensive solutions refer to models of development where the actors in the development represent several different organizational systems. Smart comprehensive solutions imply continuous renewal, foresight into the future, and learning. In public organizations, these smart comprehensive solutions can be achieved through utilizing citizen participation with personnel know-how and strengthening their use in the operation, development, and production of new solutions. Deregulation can, in the best scenarios, promote even smarter solutions. Intelligence can be developed through leadership, renewing the services, and utilizing technology (VIRTANEN; STENVALL, 2014).

Society changes, and the environment in which public organizations function has changed. These changes have been labeled with complexity (e.g. STACEY, 2001). This complex situation is full of unidentified uncertainties. There is not enough information or understanding of the situation, and previous actions are not applicable. Virtanen and Stenvall (2015) argue that due to this complexity, smartness is aiming to adapt actions in a situation constantly open to different interpretations. This requires multiple voices and the participation of different actors. According to Herbert Simon (1947), smart decision making is based on the situation and context. Context creates the boundaries for action; it is constructed from the economic, social, and political phenomena in society. Multiple interpretations, combined with shared 
knowledge, create the best base for smart decision making. It is impossible to predict the future, but shared decision making offers a wider perspective of the task on-hand than restricted management. The smartness of an organization is based on the management and leadership.

\section{WHAT IS A SMART SERVICE?}

Early definitions of service concentrated on services as intangible goods. The definitions have devolved to encompass multidimensional conceptualizations such as service-dominant logic and service science, management, engineering, and design - or simply, service science. According to service dominant logic, service is seen as an application of specialized resources to benefit the actors themselves or others. From this perspective, the emphasis is on the actual process of doing something for and with others in order to create added value (BARILE; POLESE, 2010).

Service science defines service as a system of interaction of interdependent parts externally oriented to achieve and maintain a sustainable competitive advantage (MAGLIO; SRINIVASAN; KREULEN; SPOHRER, 2006; MAGLIO; SPOHRER, 2008). Katzan (2008) argues that a service is the provision of assistance and expertise through provider-client interaction to create and capture value in business, education, government, and personal endeavors.

The unseen rise of digital technologies has led to the transformation of current business models and the creation of new ones. Many of these business models are called smart X scenarios: for example, smart factory, smart home, smart logistics, smart energy, smart mobility, and smart health. In all these scenarios, technology is used to digitally connect resources and actors for the sake of value co-creation. Therefore, smartness defined this way is limited to connecting by utilizing technology (BEVERUNGEN; MATZNER; JANIESCH, 2017). On the other hand, some authors (TÖYTÄRI et al., 2017) have limited the term "smart services" to include only industrial services.

The aim with linking physical goods with information technology is often to create and capitalize on smart service as a new or transformed good or services that offer and provide value-in-use to customers. As digital technologies have increased immensely, scholarly publications increasingly use the term "smart service." However, Beverungen et al. (2017) argue that it is still unclear and open to debate about what exactly makes service systems "smart" (and "not smart"). Smart services have also left their mark on different spheres of society (BEVERUNGEN; MATZNER; JANIESCH, 2017).

Social and health care is rarely about tangible goods or even services. The Finnish social and health care sector is a complex system that is organized differently in each municipality (VALKAMA, 2008). In Finland, 
the system has been administered by the Ministry of Social Affairs and Health since 1968 (SOSIAALI- JA TERVEYSMINISTERIÖ, 2011.) The social and health care services are seen as an entity with multiple joint tasks and spheres of operation (MÖNKKÖNEN, 2002). Therefore, it is common to use the term "social and health care services" vaguely, without concretely defining what are we are actually talking about. To simplify, social and health care can be divided administratively into the state and municipal levels. On the local level, municipalities are responsible for providing sufficient social and health care services.

\section{SMART SERVICE SYSTEM}

Maglio and Spohrer (2008) defined "service system" as a configuration of people, technologies, organizations, and shared information, able to create and deliver value to providers, users, and other interested entities through service in order to benefit each other. Maglio, Vargo, Caswell, \& Spohrer (2009) argue that service systems differ from other types of sociotechnical systems in their dependence on entities sharing capabilities to increase mutual value. A change in service systems often transforms the way systems work by embedding sophisticated capabilities into technologies, such as self-service technologies to generate more overall value (e.g. CAMPBELL; MAGLIO; DAVIS, 2011). It should be noted that value creation is difficult to measure and anticipate in service systems. Service systems not only depend on people, information, organizations, and technologies, but also on the interactions between them. This interaction can have emerging consequences. Maglio, Kwan, \& Spohrer (2015) place this interaction as the key issue in understanding service systems. The most important issue to comprehend is the critical role of people and their relationships with other components, such as information and technology. In their commentary, Maglio et al. (2015) continue: "effective understanding of complex human-centered service systems requires a new approach that combines multiple methods, perhaps drawing from industrial engineering and operations research, social and behavioral sciences, information systems, and computer science and computational modeling."

Smartness can be evaluated through different perspectives. Services can be smart from the organizational perspective, management perspective, end-user/customer perspective, or society's perspective. As already was pointed out, social and health care are not just services per se. In social and health care, society and the individual are always central. The ethos behind the whole sector is on the wellbeing and security of the whole society and therefore the individuals forming the society. The logic behind this system is different from other more traditional service systems. To blindly implement theories, actions, and principles from another sector would be short-sighted, and therefore it is crucial to adapt implementations to the sector or area. 
For example, in recent years social work has sought to emphasize the introduction of technologies based on practices. In some discussions, technology is seen as an opportunity to produce new and innovative work practices in the social and health sectors. For example, technology offers an opportunity to reach a larger proportion of the population and provide support that is not available for existing services. Positive expectations must also be critical and consider the ethical aspects associated with the use of technology (KAIRIALA, 2018).

Technology offers opportunities especially in information system production and management. An example of a customer-engaging technological application is customer information systems, where information is produced in the system together with the customer. Technology can also strengthen social reporting that can be used in structural advocacy. In social and health care interventions, technologies can be utilized in networking and online guidance. In general, communication and collaboration with different actors will make it easier to make a difference through web-conferencing applications. Collaborative platforms also provide new arenas for the development of social and health care. The flexibility, agility, accessibility, and efficiency of services are enhanced by the use of e-services. However, none of these positive results can be realized if new technologies are introduced in a technology-driven or organizationally oriented way (KAIRIALA, 2018).

The use of technology has so far been the easiest way to connect to management and management goals. However, intelligent services also require information based on social theories on the social impact of communality, interaction, and technologies. Intelligent services should be built from the outset to support citizens' inclusion and equality on a sustainable basis. It is therefore important to identify and anticipate how technology might act as a disincentive or create digital gaps for vulnerable customers (KAIRIALA, 2018).

\section{CONCLUSIONS}

Smart social and health care secures wellbeing for all and for a safe society. The service provision is based on legislation and legislative obligation. Different trends in business, management, and markets also put their stamp on rhetoric in policy making. Therefore, there are competing paradigms that affect social and health care. A need for economic efficiency, social justice, and promoting individualism compete in the social and health sector. The global rhetoric aims to change the practices and has also influenced the organizations. Organizational and institutional isomorphism refers to organizations' tendency to look like each other due to the pressures of coercive, mimetic, and normative isomorphism (DIMAGGIO; 
POWELL, 1991). The same way organizations change to mimic each other is the same way people try to change the way of organizing services. Introducing digital or e-services to all spheres in society is one example. This trend of mimicking other fields of business while paying close attention to the ethos, context, and values in social and health care requires a high level of professionalism.

The future learning needs of professionals in health and social services are substance and generic competences. Substance competence specific to professional fields will form the core learning needs of the future. In addition, a generic learning need of all professional groups in the health and social care sector is concerned with competence in working with users, developing services, and managing changes related to employment and collaboration (KANGASNIEMI et al., 2018).

In the future, this means that generic know-how, such as customer orientation in service production, leadership, and service development and design, is not just a professional challenge, but above all an organizational issue. Intelligence refers to customer-oriented, collaborative interactivity in the social and health care context that integrates digitalization in a socially sustainable way into social and health management structures. Intelligent services enable the implementation and management of new and agile customer processes, where customers and their processes are at the heart of the operation. This also enables process management and the systematic monitoring and development of the effectiveness of services. In the future, smart social and health care is not just smart services. A smart social and health care system needs user-led management and service design.

\section{REFERENCES}

BARILE, S.; POLESE, F. Service Dominant Logic and Service Science: a contribute deriving from network theories, In: GUMMESSON, E.; MELE, C.; PLESE, F. (eds.) The 2009 Naples Forum on Service: service Science, S-D logic and network theory. Napoli: Giannini, 2009. pp. 21-40.

BEVERUNGEN, D.; MATZNER, M.; JANIESCH, C. Information systems for smart services. Information Systems and E-Business Management, v. 15, no. 4, pp. 781-787, 2017. Available at: <https://doi. org/10.1007/s10257-017-0365-8> Accessed on: 26 June. 2019.

BLOMBERG-KROLL, H. Kosta vad det kosta vill? Attitydmönster och attitydförändringar hos befolkningen och eliter beträffande välfärdsservicen i nedskärningarnas tid. Akademisk avhandling. Vaasa: Åbo Akademi, 1999. 
BLOMBERG-KROLL, H. Strong support for the Nordic model. In: What role will the Nordic welfare model play in globalization? Conference report. p. 16, 2011. Available at: <https://nordicwelfare.org/ wp-content/uploads/2017/10/Konferensrapport.pdf> Accessed on: 26 June. 2019.

CAMPBELL, C. S.; MAGLIO, P. P.; DAVIS, M. M. From self-service to super-service: How to shift the boundary between customer and provider. Information Systems and eBusiness Management, v. 9, no. 2, pp. 173-191, 2011.

DIMAGGIO, P. J.; POWELL, W. The Iron Cage Revisited: Institutional Isomorphism and Collective Rationality in Organizational Fields. The New Institutionalism in Organizational Analysis. Chicago: University of Chicago, 1991.

FORAY, D. Smart Specialisation: Opportunities and Challenges for Regional Innovation Policy. London: Routledge, 2015.

FORAY, D.; DAVID, P.; HALL, B. Smart Specialisation - The Concept. Knowledge Economists Policy Brief Nr. 9, 2009. Available at: <http://ec.europa.eu/invest-in-research/pdf/download_en/kfg_policy_brief_ no9.pdf> Accessed on: 26 June. 2019.

HAAVISTO, I.; KILJUNEN, P. Maailman paras maa. EVAn kansallinen arvo-

ja asennetutkimus 2011. Helsinki: Taloustieto, 2011.

HYPPÖNEN, H.; ILMARINEN, K. Sähköisten sosiaali- ja terveyspalvelujen tarjonta, palvelujen käyttö ja esteet. In: KESTILÄ, L.; KARVONEN, S. (Eds.). Suomalainen hyvinvointi 2018. Helsinki: Terveyden ja hyvinvoinnin laitos, 2019. pp. 279-290.

JULKUNEN, R. Kuka vastaa? Hyvinvointivaltion rajat ja julkinen vastuu. Helsinki: Stakes, 2006.

KAIRIALA, M. Sosiaalityön teknologiaosaaminen. In: JUVONEN, T.; LINDH, J.; POHJOLA, A.; ROMAKKANIEMI, M. (Eds.). Sosiaalityön muuttuva asiantuntijuus. Sosiaalityön tutkimuksen vuosikirja 2018. Helsinki: UNIpress, 2018. pp. 211-227.

KANGASNIEMI, M.; HIPPI, P.; HÄGGMAN-LAITILA, A.; KALLIO, H.; KÄRKI, S.; KINNUNEN, P; PIETILÄ, A.-M.; SAARNIO, R.; VIINAMÄKI, L.; VOUTILAINEN, A.; WALDÉN, A. Optimoitu sote-ammattilaisten koulutus-ja osaamisuudistus. Valtioneuvoston selvitys- ja tutkimustoiminnan julkaisusarja 39/2018, 2018. 
KATZAN, H. Foundations of Service science concepts and facilities. Journal of Service Science, v. 1, no. 1, pp. 1-22, 2008.

LEHTO, M. Sosiaalipolitiikka edistyksen asialla. Tampere: Vastapaino, 2001.

MAGLIO, P. P.; SPOHRER, J. Fundamentals of service science. Journal of the Academy of Marketing Science, v. 36, no. 1, pp. 18-20, 2008.

MAGLIO, P. P.; VARGO, S. L.; CASWELL, N.; SPOHRER, J. The service system is the basic abstraction of service science. Information Systems and e-business Management, v. 7, pp. 395-406, 2009.

MAGLIO, P. P.; KWAN, S. J.; SPOHRER, J. Toward a research agenda for human-centered service system innovation. (Commentary). Service Science, v. 7, no. 1, pp. 1-10, 2015.

MARCH, J. K. The Pursuit of Intelligence in Organizations. In LANT, T. K.; ZUR, S. (Eds.). Organizational Cognition: Computation and Interpretation. Lawrence Erlbaum Associates, Publishers: Mahwah, New Jersey London. pp. 50-58, 2001.

MATHESON, D.; MATHESON, J. E. Smart Organisations Performs Better. Research and Technology Management. pp. 49-54. July-August 2001.

MUURI, A.; AALTO, A.-M.; MANDERBACKA, K.; ARFFMAN, M. Sosiaali- ja terveydenhuollon kannatusperusta väestössä. In: KESTILÄ, L.; KARVONEN, S. (Eds.). Suomalainen hyvinvointi 2018. Helsinki: Terveyden ja hyvinvoinnin laitos, 2019. pp. 292-304.

MÄLKIÄ, M. Kieli, vuorovaikutus ja valta tietoyhteiskunnassa. Hallinnon tutkimus, v. 17, no. 3, pp. 173191, 1998.

MÖNKKÖNEN, K. Dialogisuus kommunikaationa ja suhteena. Kuopion yliopiston julkaisuja E. yhteiskuntatieteet 94. Kuopio: Kuopion yliopisto, 2002.

NIIRANEN, V. Asiakkaan osallistuminen tukee kansalaisuutta sosiaalityössäkin. In: JUHILA, K.; FORSBERG, H.; ROIVANEN, I. (Eds.). Marginaalit ja sosiaalityö. Jyväskylä: SoPhi. 2002, pp. 63-80.

SILTANIEMI, A.; PERÄLAHTI, A.; ERONEN, A.; SÄRKELÄ, R.; LONDÉN, P. Kansalaisbarometri. Suomalaisten arvioita hyvinvoinnista, palveluista ja PARASuudistuksesta. Helsinki: Sosiaali- ja terveysturvan keskusliitto ry, 2009. 
SIMON, H. Administrative Behavior: a Study of Decision-Making Processes in Administrative Organization. New York: The Macmillan Company, 1947.

SOSIAALI- JA TERVEYSMINISTERIÖ (2011). Suurruhtinaskunnasta hyvinvointiyhteiskuntaan, 2011. Available at: <http://www.stm.fi/stm/historia> Accessed on: 26 June. 2019.

STACEY, R. D. Complex responsive processes in organizations: Learning and knowledge creation. London and New York: Routledge, 2001.

VALKAMA, K. Verkostoja, palveluketjuja vai palvelukokonaisuuksia? Tapaustutkimus autismin kirjon lapsiperheiden kokemuksista hyvinvointijärjestelmässä. Unpublished licentiate thesis, 2008.

VALKAMA, K. Asiakkuuden dilemma - Näkökulmia sosiaali- ja terveydenhuollon asiakkuuteen. Vaasa: Vaasan yliopisto. 2012.

VARGO, S. L.; LUSCH, R. Service-dominant logic: continuing the evolution. Journal of Academy of Marketing Sciences, v. 36, pp. 1-10, 2008.

VIRKKALA, S. Älykäs erikoistuminen ja alueelliset innovaatiojärjestelmät talouskasvun lähteenä. Talous ja yhteiskunta no. 3, pp. 42-46, 2015.

VIRTANEN, P.; STENVALL, J. Älykkäiden Julkisorganisaatioiden Aika. In: AF URSIN, K., PEKKOLA, E.; STENVALL, J. (Eds.). Felix byrokratia? Julkinen hallinto kaiken huomioimisen taitona, 2015. pp. 303-318. Available at: <https://tampub.uta.fi/bitstream/handle/10024/101427/alykkaiden_ julkisorganisaatioiden_aika.pdf> Accessed on: 26 June. 2019.

VIRTANEN, P.; STENVALL, J. Älykäs julkinen organisaatio. Helsinki: Tietosanomat, 2014.

YOLLES, M. Organisational intelligence. Journal of Workplace Learning, v. 17, nos. 1-2, pp. 99-114, 2005. Available at: <https://doi.org/10.1108/13665620510574496> Accessed on: 26 June. 2019. 